TID-4500, UC-35

Nuclear Explosions -

Peaceful Applications

TID-4500, UC-70

Waste Disposal and

Processing

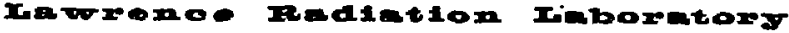 \\ UHIVERSITY OF GALIFOAHIA \\ IIVERBOAE \\ 94550 \\ UCRL-51044 \\ USE OF A DEEP NUCLEAR CHIMNEY \\ FOR THE IN-SITU INCORPORATION \\ OF NUCLEAR FUEL-REPROCESSING WASTE \\ AN MOLTEN SILICATE ROCK
}

Jerry J. Cohen

Arthur E. Lewis

Robert L. Braun

This roport was prepared as an account of work sponsorod by the United States Government. Neither

the United States nor the Unite? States Atomic Energy

remmission, nor any of their employees, nor any of

thoir contractors. subcontractors, or .their employees,

mokes any warronty, express or implied, or assumes any

legal liablity or responsibility for the accuracy, com-

pletonest or usefulness of ony information, opparotus,

product or process diaclosed, or rapresents that its use

would not inftinge privately owned rights. 


\section{Contents}

Abstract . . . . . . . . . . . . . . . . 1

Introduction

Backg,sound

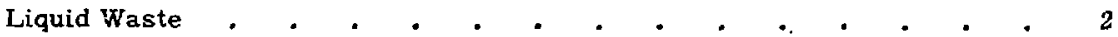

Fxisting and Proposed Liquid-Waste-Drsposal Practices . . . . 2

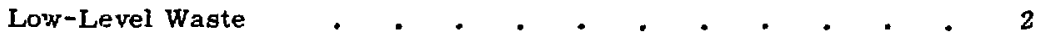

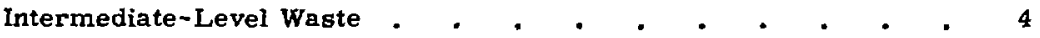

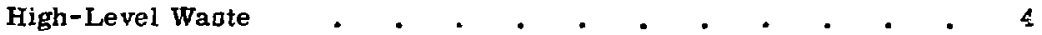

The Plowshare Concept . . . . . . . . . . . . . 5

Heat Balance . . . . . . . . . . . . . . . 7

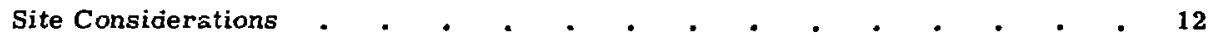

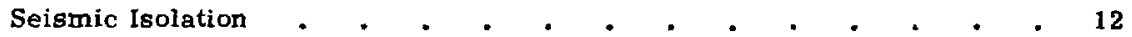

Geology and Hydrology

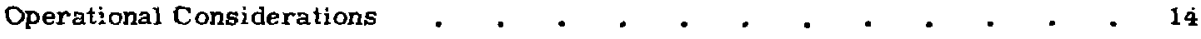

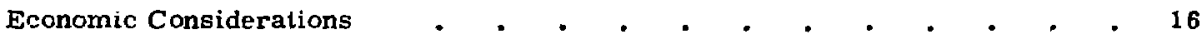

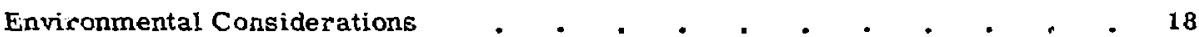

Simmary and Conclusions $\quad . \quad$. . . . . . . . . . . . . . 18

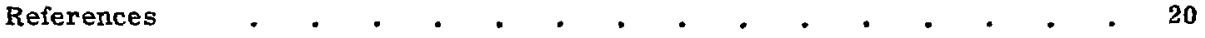




\title{
USE OF A DEEP NUCLEAR CHIMNEY FOR THE IN-SITU INCORPORATION OF NUCLEAR FUEL-REPROCESSING WASTE IN MOLTEN SILICATE ROCK
}

\begin{abstract}
A method for disposing of nuclearreactor wastes by in-situ incorporation in molten silicate rock is presented. In this method. liquid wastes are injected into a deep underground chimney and allowed to self-boil. The resulting stcam is processed at the ground surface and recycled into a closed system. When waste addition is terminated, the chimney

is allowed to boil dry, thereby solidifying the waste. The heat generated by the radioactive waste then meits the surrounding rock, which dissolves the waste. Finally, the rock refreezes, trapping the radioactivity in an insoluble rock matrix deep underground. This method has significant environmental and economic advantages over previously proposed methods.
\end{abstract}

\section{Introduction}

One of the most formidable problems that remains in the development of nuclear power is the management of radioactive wastes from nuclear fuel-reprocessing plants. ${ }^{1}$ Because of their extremely high hazard and long decay times, these wastes must be isolated from the biosphere for many centuries. During the past 20 years, considerable money and effort have been devoter to determining the best solution to the problem. This effort has resulted in an $A E C$ policy ${ }^{2}$ requiring high-level wastes to be removed from solution, incorporated in an insoluble solid material, and shipped to centralized repositories for permanext emplacement.
This AEC policy, has been criticized for both economic and environmental reasons. $1,3,4$ However, it is generally considered to be the only technicall; $;$ acceptable alternative to present methods of waste storage in surface tanks. 5 This report discusses a concept for an integrated nuclear fuel-reprocessing and waste-disposai facility that we believe would be both safer and less expensive than previously considered techniques. The riathod would use deep nuclear chimneys ${ }^{6}$ for the in-situ incorporation of fuel-reprocessing waste in molten silicate rock, 


\section{Background}

Nuclear fuel-reprocessing plants are by far the major producers of radioactive waste materials. At these plants, spent fuel elements from nuclear reactors are processed to remove accumulated fission products and to produce purified fissionable material for subsequent fabrication into new fuel elements. The most prominent reprocessing method is the "Purex" process, which consists essentially of the following steps:

1. Shearing of the fuel elements to rupture the corrosion-resistant cladding and expose the fuel.

2. Dissolution of the fuel in nitric acid.

3. Solvent extraction and ion exchange to separate and purify the uranium and plutorium.

The radioacrive waste produced from these operations is predominantly in the form of aqueous solutions and is referred to as "liquid waste."

\section{LIQUID WASTE}

Liquid waste is categorized into high-, intermediate-, and low-level waste according to its concentration of radioactivity.
Specific definitions of these categories differ among various nuclear installations. Table 1 gives the concentration ranges set at two nuclear installations, along with standard definitions proposed by the American Institute of Chemical Engineers. ${ }^{7}$

The radioactive content of liquid wastes is dependent on such factors as the burnup rate, the neutron flux, and the time aince the fuel was removed from the reactor. The fuel-reprocessing method determines the overall chemical composition of liquid waste. For the purposes of this report, properties consistent with those given in Ref, 5 are assumed. A summary of these properties is given in Table 2 .

Projections of future needs for nuclear fuel $i$ eprocessing in this country are given in Table 3. Figure 1 gives the anticipated accumulation of isotopic activity in waste systems for the next $50 \mathrm{yr}$.

\section{EXISTING AND PROPOSED LIQUID- WASTE-DISPOSAL PRACTICES}

\section{Low-Level Waste}

Many different processes for treating low-level Iiquid wastes are in use at various nuclear establishments. They are

Table 1. Liquid-waste definitions.

\begin{tabular}{|c|c|c|c|c|}
\hline \multirow[b]{2}{*}{ Level } & \multicolumn{2}{|c|}{ ORNL $^{2}$} & \multirow{2}{*}{$\begin{array}{l}\text { HANFORD } \\
(\mu \mathrm{Ci} / \mathrm{ml})\end{array}$} & \multirow{2}{*}{$\begin{array}{c}\text { AICE } \\
(\times M P C)^{c}\end{array}$} \\
\hline & $(\mu \mathrm{Ci} / \mathrm{ml})$ & $(\times \mathrm{MPC})^{\mathrm{c}}$ & & \\
\hline Low & $10^{-5}$ to $10^{-2}$ & 10 to $10^{4}$ & $<5 \times 10^{-5}$ & $<10^{4}$ \\
\hline Intermediate & $10^{-2}$ to 1 & $10^{4}$ to $10^{6}$ & $5 \times 10^{-5}$ to 100 & $10^{4}$ to $10^{8}$ \\
\hline High & -1 & $>10^{6}$ & $>100$ & $>1 n^{8}$ \\
\hline
\end{tabular}

aak Ridge National Laboratory.

${ }^{b}$ American Institute of Chemical Engineers.

$c_{M P C}=$ maximum permissible concentration. 
Table 2. Summary of the assumed characteristics of nuclear fuel-reprocessing wastes.

Spent-fuel history

Reartor neutron flux (neutrons $/ \mathrm{cm}^{2}-\mathrm{sec}$ )

Specific power (MW/ton) ${ }^{\mathrm{C}}$

$\begin{array}{cc}\text { LWR }^{a} & L M F B R^{b} \\ 2.9 \times 10^{13} & 2.6 \times 10^{15} \\ 30 & 58 \\ 3.3 \times 10^{4} & 3.3 \times 10^{4}\end{array}$

Burnup (MWd/ton)

Ceneral

\begin{tabular}{lc} 
& $\begin{array}{c}\text { Quantity per } \\
\text { ton of fuel } \\
\text { processed }\end{array}$ \\
\hline Fission-product isotopes $(\mathrm{kg})$ & 35 \\
Actinides $(\mathrm{kg})$ & 5.8 \\
Total $(\mathrm{kg})$ & 40.8 \\
Volume of solidified dry wastes $\left(\mathrm{ft}^{3}\right)$ & 3.3 \\
Volume of liquid waste & $\left(0.093 \mathrm{~m}^{3}\right)$ \\
High-level waste (gal) & $400\left(1.52 \mathrm{~m}^{3}\right)$ \\
Intermediate and low -level waste (gal) & $10,000\left(37.85 \mathrm{~m}^{3}\right)$
\end{tabular}

Decay

Total curies at a postirradiation time of

\begin{tabular}{|c|c|c|c|c|c|c|c|}
\hline \multirow{3}{*}{$L W R^{2}$} & & $0.25 \mathrm{yr}$ & $0.41 \mathrm{yr}$ & $1.0 \mathrm{ys}$ & $10 \mathrm{yr}$ & $100 \mathrm{yr}$ & 1000 y $F$ \\
\hline & $\begin{array}{l}\text { Fission } \\
\text { products }\end{array}$ & $6.2 \times 10^{6}$ & $4.4 \times 10^{6}$ & $2.2 \times 10^{6}$ & $3.2 \times 10^{5}$ & $3.4 \times 10^{4}$ & 21 \\
\hline & Actinides & $2.3 \times 10^{4}$ & $1.8 \times 10^{4}$ & $9.2 \times 10^{3}$ & $2.4 \times 10^{3}$ & $3.3 \times 10^{2}$ & 85 \\
\hline \multirow{3}{*}{$\mathrm{LMFBR}^{\mathbf{b}}$} & & $0.08 \mathrm{yr}$ & $1.0 \mathrm{yr}$ & $3.0 \mathrm{yr}$ & $10 \mathrm{yr}$ & $100 \mathrm{yr}$ & $1000 \mathrm{yr}$ \\
\hline & $\begin{array}{l}\text { Fission } \\
\text { products }\end{array}$ & $2.0 \times 10^{7}$ & $3.4 \times 10^{6}$ & $1.0 \times 10^{6}$ & $2.8 \times 10^{5}$ & $3.1 \times 10^{4}$ & 25 \\
\hline & Actinides & $7.9 \times 10^{4}$ & $2.2 \times 10^{4}$ & $6.7 \times 10^{3}$ & $5.0 \times 10^{3}$ & $2,0 \times 10^{3}$ & $5.0 \times 10^{2}$ \\
\hline
\end{tabular}

\footnotetext{
a Light-water reictor.

biquid-metal-isooled fast breeder reactor.

In this report, "ton" refers to "metric ton" (1000 kg).
}

designed to reduce the radioactive content of the waste to :evels considered acceptable for release to the environment. Among the methods used for low-level waste treatment are shemical cosgulation and precipitation, ion exchange, electro- dialysis, filtration, and dilution, ${ }^{9} \mathrm{~A}$ method apparently coming into increasing favor is underground disposal by means of injection into porous layers deep underground. ${ }^{10}$ No individual method is presently officially advocated for disposal of 
Table 3. Projected growth of nuclear power and fuel-reprocessing capacity in the United States,

\begin{tabular}{lccc}
\hline Iear & $\begin{array}{c}\text { Installed capscity } \\
\left(10^{3} \mathrm{MW}_{\mathrm{e}}\right)\end{array}$ & $\begin{array}{c}\text { Fuel-reprocessing } \\
\text { load } \\
\text { (tons } / \mathrm{yr} \text { ) }\end{array}$ & $\begin{array}{c}\text { Total accumulated } \\
\text { waste radioisotopes } \\
\text { (tons) }\end{array}$ \\
\hline 1970 & $\overline{(6.1)^{\mathrm{a}}}$ & 94 & 1.75 \\
1980 & $\begin{array}{c}153 \\
(147)^{\mathrm{a}}\end{array}$ & 3,500 & 451 \\
1990 & $\begin{array}{c}368 \\
(500)^{\mathrm{a}}\end{array}$ & 13,500 & 2,440 \\
2000 & 735 & 15,000 & 6,200 \\
2020 & 2,210 & 33,000 & 24,600 \\
\hline
\end{tabular}

${ }^{a}$ Estimates in parentheses are taken from Ref. 8; all other figures are taken from Ref. 5.

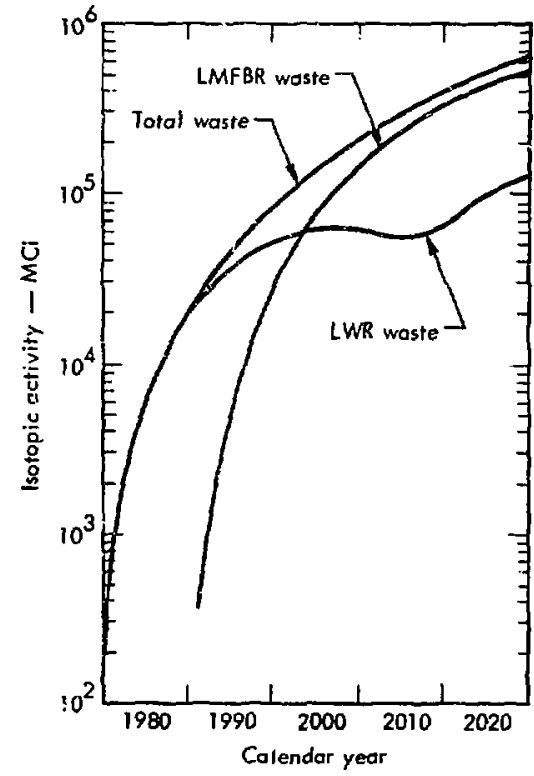

Fig. 1. Totai accumulated radioactivity in wastes generated by reprocessing spent fuels from lightwater reactora (LWR) and liquidmetal-cooled fast breeder reactors (LMFBR). This graph is taken from Ref. 5. low-level waste. Because of the diversity of conditions under which such waste is generated, at reprocessing plants as well as other types of nuclear establishments, it is unlikely that any single method would suffice for all facilities.

\section{Intermediate-Level Waste}

No treatment methods are designated as being specifically applicable to intermediate-level wastes. These wastes are eicher treated as high-level wastes or in such a manner that their radioactive content is reduced to where they can be managed as low-level wastes.

\section{High-Level Waste}

Over $99.9 \%$ of the activity in all radioactive waste is generated in the form of high-level liquid waste. Until recently, no generally accepted policy for the management of this highly hazardous material hæd been set. In anticipation of such a policy, an "interim" solution to this problen. 
has been used for over $25 \mathrm{yi}$. Highlevel waste in the form of solutions, suspensions, and solidified material has been stored in tanks at or near the earth's surface. As a result of this practice, over 80 million gal of this material have accumulated at AEC installations. This situation has greatly distressed those concerned with environmental protecticn. ${ }^{1}$ In addition to the fact tizat several tank leaks have been detected, ${ }^{11}$ the possibility exists of some natural or manmade $d$ is aste $r$ befalling a tank storage area.
One possible means of permanent disposal of these stored wates is underground injection into mined cavities in deep crystalline rock, ${ }^{12}$ The primary drawbacks of this approach are high cost and concern over possible hydrologic transport resulting in aquifer corstamination.

The present AEC policy for the management of high-level wastes requires transformation of the liquid waste into an approved solid form (such as an insoluble glass) and shipment to centralized federal repositories for perpetual storage and surveillance.

\section{The Plowshare Concept}

We propose a method of radioactivewaste disposal that meets the objective of safe, permanent, and timely removal of radioactive material from the biosphere at relatively low cost. It involves the placement and self-processing of the wastes in deep underground rubble-filled voids (chimneys), which are best created by nuciear explosives. This method is referred to here as the Plowshare concept.

The concept is depirted in Fig. 2, The capacities and properties indicated in Fig. 2 are given as reasonable examples, not as requirements. To eliminate the need for waste transportation, the disposal chimney is situated in the immediate vicinity of the nuclear fuel-reprocessing plant. The chimney would be iormed in deep silicate rock having a low permeability.

Iiquid wastes resulting from the plant operations would be injected into the chimney with either minimal treatment or

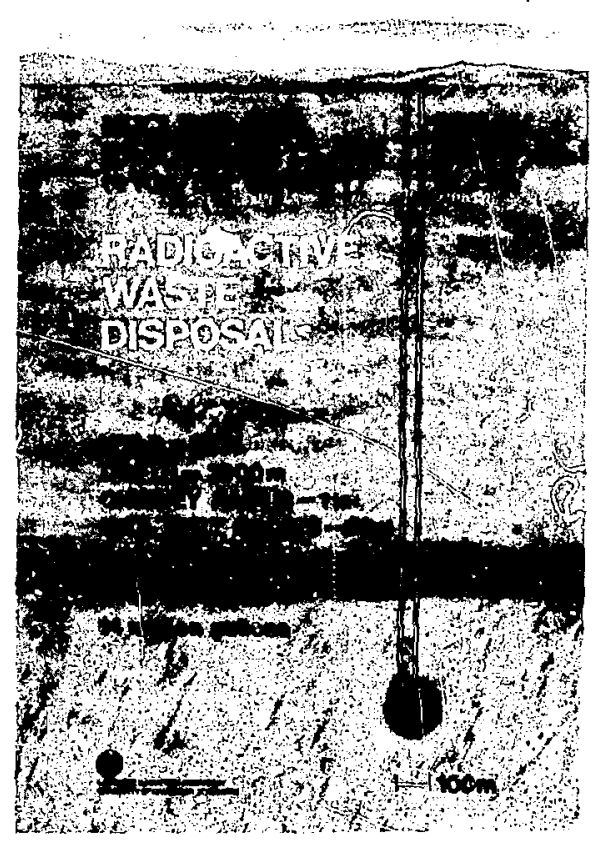

Fig. 2. Artist's concept of waste dis posal in a nuclear chimney. 


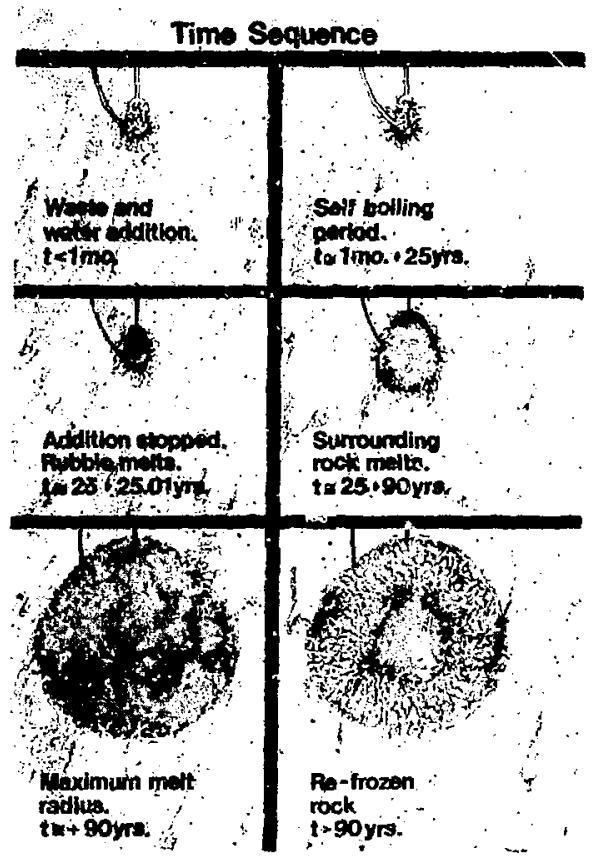

Fig. 3. Artist's concept of the sequence of events that occur in the chimney when liquid waste is added.

none at all. Initially, only frest highlevel wastes would be injected and allowed to self-boil in the chimney. The resulting vapor would be allowed to escape through a vent to the surface. As suon as enough radioactive material is accumulated to assure continuous boiling, intermediateand low-level waste wouid he added. As the process continues, radioactivity would accumulate and require additional cooling water to prevent the chimney from meliing. The temoerature would be maintained well below the melting point of the rock by regulating the rate of water additicn. At the surface, steam issuing from the vent would be condensed and recirculated to cool the chimney or processed for reuse in the plant. The closed system would insure no release of contamination to the environment.

When the chimney reaches its capacity tby having its interstitial volume filled with solidified waste), or is no long? needed, waste and water addition would be terminated and the inlet hole would be permanently sealed. When steam and vapor are nolonger released, the vent would also be sealed.

In the chinney, the events depicted in Fig. 3 would then occur. For purposes of this description, a $25-\mathrm{yr}$ waste-addition period is assumed. The indicated time spans are based on the plant operating conditions given in Fig. 2 and on heatflow calculations that are discussed later.

When waste and water addition stops, the chimney temperature would rapidly rise to the melting point of the rock and melting would commence. The chimney rubble would melt first, followed by the surrounding rock. The radioactive material would dissolve in the rock melt. As the molten rock mass increases in size, its surface area increases, resulting in a higher rate of conductive heat loss to the surrounding rock. Concurrently, the heat production zate of the radioactivity diminishes due to decay. When the rate $c f$ heat loss exceeds that of input, the molten rock will begin to cool and solidify. During this perisd, no environmental hazard could result since the molten rock mass would be essentially imrobile (movement to any cooler environment would cause rapid solidification). The heat surrounding the radioactivity would prevent the intrusion of groundwater. The ultimate result would be the permanent incorporation of the waste in an insoluble silicate rock matrix deep underground. 


\section{Heat Balanc:}

Consideration of heat generation and transport within the chimney and the surrounding rock is essential to an understanding of the Plowshare concept.

The calculated thermal power ${ }^{5}$ of fission products and actinides in the wastes generated by the processing of spent fuels from light-water reactors (LWR) and liquid-metal-cooled fast breeder reactors (LMFBR) is summarized in Table 4. Figure 4 shows the total thermal power in the processing waste from each spent fuel as a function of postirradiation times between $6 \mathrm{mo}$ and $100 \mathrm{yr}$.

If we assume that the waste to be disposed of consists of equal amounts of LWR and LMFBR waste, then thermal decay can be represented by the linear regression line shown in Fig. 4. That is,

$$
\dot{q}=\frac{\dot{q}_{0}}{t^{1+\alpha}}
$$

where $\dot{q}$ is the rate of heat production in the processed waste (W/ton), $\dot{q}_{0}=1.123$ $\times 10^{4}(\mathrm{~W} / \mathrm{ton})(\mathrm{yr})^{1+\alpha}$, and $\alpha=-0.0125$

(from 6 mo to $100 \mathrm{yr}$ ).

In estimating the thermal effects accompanying the underground disposal

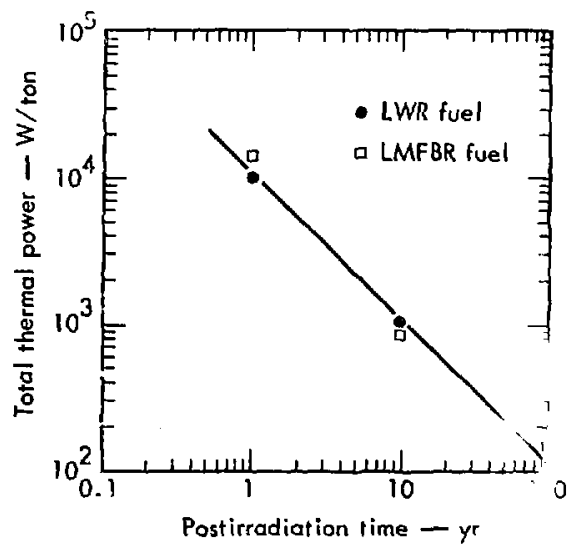

Fig. 4. Total thermal power in the wastias generated by the $p r$ cessing of spent LWR and $I$. MF $R$ fuel as a function of $p_{c}$, i $a$ adia. tion time.

of these wastes, the rate $Q$ fwatt: of heat production by the radioactive we ite in the chimney must be known as a ful..tion of time. In general, suppose that vaste having heat output $\dot{q}(W /$ ton $)$ is added to the chimney ax a rate of $\dot{V}$ ( $t, i s / y^{\prime}$ for a duration of $t_{d}(y r)$. Thereaf $r$, waste addition is terminated or waste of a different strength is added at a different rate for another duration. This process

Table 4. Thermal power of significant fission products and actinıdes in the wastes gererated by the processing of spent LWR and LMFBR fuels.

\begin{tabular}{llcc}
\hline & \multicolumn{3}{c}{ Pestirradiation time (yr) } \\
\cline { 2 - 4 } & 1 & 10 & 100 \\
\hline LWR fission products (W/ton) & $1.00 \times 10^{4}$ & $1.03 \times 10^{3}$ & $1.04 \times 10^{2}$ \\
LWR actinides (W/ton) & $3.15 \times 10^{2}$ & $7.06 \times 10^{1}$ & $1.01 \times 10^{1}$ \\
LWR total (W/ton) & $1.02 \times 10^{4}$ & $1.10 \times 10^{3}$ & $1.14 \times 10^{2}$ \\
LMFBR fission products (W/ton) & $1.38 \times 10^{4}$ & $7.66 \times 10^{2}$ & $8.12 \times 10^{1}$ \\
LMFBR actinides (W/ton) & $6.02 \times 10^{2}$ & $1.01 \times 10^{2}$ & $6.02 \times 10^{1}$ \\
LMFBR total (W/ton) & $1.45 \times 10^{4}$ & $8.67 \times 10^{2}$ & $1.47 \times 10^{2}$ \\
\hline
\end{tabular}


can be continued for $\underline{n}$ auch phases of waste disposal. Analytically,

$$
\dot{Q}=\sum_{j=1}^{n} \dot{Q}_{j}
$$

where

$$
\begin{aligned}
& \dot{Q}_{j}=\int_{t_{0}}^{t_{0}+t_{j}} \dot{v}_{j} \dot{q}_{j} d t-\int_{t_{0}}^{t_{0}+t_{j}-t} d j \\
& \dot{v}_{j} \dot{q}_{j} d t \\
&=\int_{t_{0}+t_{j}-t}^{t_{0}+t_{j}} \dot{v}_{j} \dot{q}_{j} d t
\end{aligned}
$$

where $\dot{Q}_{j}$ is the contribution to the net rate of heat production in the chimney due to waste added during phase $j, t_{0}$ is the age $(\mathrm{yr})$ of the waste at the time of disposal, $t_{j}$ is the total time $(\mathrm{yr})$ elapsed since the start of phase $j$, and $t_{d j}$ is the duration (yr) of vraste dispusal in phase $j$.

The integrals of Eq. (3) can be understood by the following considerations. The first integral would be the rate of heat production if waste were added during the entire time interval $\mathbf{t}_{j}$. However, since waste is actually added only during $t_{d j}$, the rate of heat production from waste not added during the time interval $t_{j}-t_{d_{j}}$ (second integral) must be aubtracted to give the actual rate of heat production (third integral). Thus; the limits of the latter integral take into account that at an elapsed time $t_{j}$ since the start of phase $j$, the age of the waste added during $t_{j}$ ranges from $t_{0}+t_{j}-t_{d j}$ to $t_{0}+t_{\mathrm{j}}$. Substituting Eq. (1) into Eq. (3),

$$
\dot{Q}_{j}=\int_{t_{0}+t_{j}-t}^{t_{0 j}+t_{j}} \frac{\dot{v}_{j} \dot{q}_{0}}{t^{1+\alpha}} d t .
$$

For $\alpha \neq 0$,

$$
\dot{Q}_{j}=\frac{\dot{V}_{j} \dot{q}_{0}}{\alpha}\left[\frac{1}{\left(t_{0}+t_{j}-t_{d j}\right)^{\alpha}}-\frac{1}{\left(t_{0}+t_{j}\right)^{\alpha}}\right] \text {, }
$$

and for $\alpha=0$.

$$
\dot{Q}_{j}=\dot{V}_{j} \dot{q}_{0} \ln \frac{t_{0}+t_{j}}{t_{0}+t_{j}-t_{d j}} .
$$

The following model is proposed for understanding the disposition of the heat generated in the chimney. The "primary" system at time $t_{i}$ is defined as $z$ sphere of radius $r_{i}$ having a uniform temperature $T_{i}$ and containing a volume $V_{w, i}$ of water, a volume $V_{S, i}$ of chimney rubble immersed in water or vater vapor, and a volume $V_{m, i}$ of molten rock. Knowing these properties at time $t_{i-1}$, we can calculate them at time $t_{i}=t_{i-1}+\Delta t$. The assumption of sphericity is made to facilitate the calculation of heat transfer by thermal conductivity.

The latter calculation is based upon the following spatial zoning. Zcne 1 is defined as a sphere whose volume is equivalent to the volume of the chimney rubble. The remaining zones are defined as spherical shells of some prescribed thickness. The rate $P_{x y}$ (cal/sec) of heat transfer between zones $x$ and $y$ is then

$$
P_{x y}=-4 \pi r_{x y}^{2} K\left(\frac{d T}{d x}\right)_{x y}
$$

where $r_{x y}$ is the radial distance from the center of the spherical system to the $x y$ interface and $(\mathrm{d} T / \mathrm{dr})_{x y}$ is the temperature gradient at distance $\mathbf{r}_{\mathbf{x y}}$.

A computer code HEAT, based on Egs. (2) and (7), performs the heat balance to calculate the new properties of 
the primary system for a prescribed temporal and spatial zoning for any desired scheme of waste disposal. Four distinct temperature regimes as well as the transitions between these regimes are of interest: $\mathrm{T}<100^{\circ} \mathrm{C}, \mathrm{T}=100^{\circ} \mathrm{C}, 100^{\circ} \mathrm{C}<\mathrm{T}$ $<T_{f}$, and $T=T_{f}$, where $T_{f}$ is the melting point of the rock.

$\mathrm{T}_{\mathrm{i}-1}<100^{\circ} \mathrm{C}$

The primary system consists of the water added to the chimney during time $t_{i-1}$ and the portion of the chimney rubble that is immersed in water.

$T_{i-1}=100^{\circ} \mathrm{C}$

The primary system consists of the water added to the chimney during time $t_{i-1}$ that has not yet vaporized and the portion of the chimney rubble that is immersed in water and water vapor. In these first two temperature regimes, it is assumed that there is no heat transfer by thermal conductivity into spatial zones outside the chimney until the primary system has grown to the size of zone 1 .

$100^{\circ} \mathrm{C}<\mathrm{T}_{\mathrm{i}-1}<\mathrm{T}_{\mathrm{f}}$

The primary system consists of the chimney rubble absorbing heat uniformly until the entire chimne $y$ is at the melting point.

$T_{i-1}=T_{f}$

The primary system consists of the chimney rubble absorbing heat until all chimney rubble has melted. Thereafter, the primary system remains at the melting point and moves through consecutive zones to finish raising the temperature of the next zone to its melting point and then melting it. Trìis process continues until the heat input to the primary system is balanced by the heat lost from it by thermal conductivity, whereupon cooling and solidification of the molten rock comriences.

To illustrate the magnitude of the thermal effects associated with the disposal of high-level radioactive wastes, the following representative properties are assumed.

\section{Rock Properties}

$$
\begin{aligned}
& \text { Initial } \\
& \text { temperature }=50^{\circ} \mathrm{C} \text {. } \\
& \text { In-situ } \\
& \text { density }=2.7 \mathrm{~g} / \mathrm{cm}^{3} \text {. } \\
& \text { Melting point }=1050^{\circ} \mathrm{C} \text {. } \\
& \text { Heat of } \\
& \text { fusion }^{13}=80 \mathrm{cal} / \mathrm{g} \text {. } \\
& \text { Specific } \\
& \text { heat }{ }^{14} \\
& =0.216+\left(9.60 \times 10^{-5} \mathrm{~T}\right) \\
& -\left(2.91 \times 10^{3} \mathrm{~T}^{-2}\right)(\mathrm{T} \text { in } \\
& \left.{ }^{\circ} \mathrm{K}\right) \mathrm{cal} / \mathrm{g} \text {-deg. } \\
& \text { conductivity }=\left(6.30 \times 10^{-3}\right)-\left\{6.7 \times 10^{-6} \mathrm{~T}\right) \\
& +\left(3.41 \times 10^{-9} \mathrm{~T}^{2}\right)(\mathrm{T} \text { in } \\
& \text { 'C) cal /cm-sec-deg. }
\end{aligned}
$$

The temperature dependence of thermal conductivity for silicate rock, extrapolated by analogy with other silicates for which such data are known, ${ }^{15}$ is shown in Fig. 5.

$$
\begin{aligned}
& \text { Assumed Waste Properties } \\
& \dot{\mathrm{V}}=1500 \text { tons of fuel } / \mathrm{yr}=5 \times 10^{5} \mathrm{gal} \\
& \text { of water/yr. } \\
& \dot{q}_{0}=1.123 \times 10^{4}(\mathrm{~W} / \text { ton })(\mathrm{yr})^{1+\alpha} \\
& =28.075(\mathrm{~W} / \mathrm{gal})(\mathrm{vr})^{1+\alpha} \text {. } \\
& \alpha=-0.0125 \text {. } \\
& T_{w}=99^{\circ} \mathrm{C} \text { (temperature of the waste). }
\end{aligned}
$$

\section{Chimney Properties}

The relevant data for 5-, 10-, and 30-kt chimneys are shown in Table 5 . These 


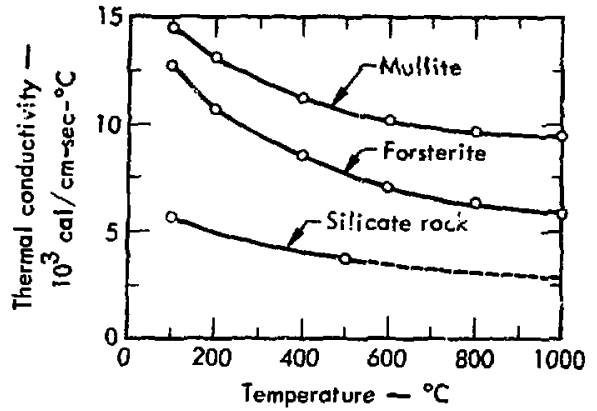

Fig. 5. Thermal conductivity versus temperature.

data were calculated by formulas of Butkovich and Lewis, ${ }^{16}$ using a depth of burial of $2000 \mathrm{~m}$, a water content of the rock of $2 w t \%$, a scaling constant of 100 , end an in-situ density oî $2.7 \mathrm{~g} / \mathrm{cm}^{3}$.

\section{Calculational Results}

Heat-flow calculations were performed for various conditions. The results of a typical calculation are given in Figs, 6 through 9 . This calculation assumed the following conditions:

1. Chimney formed by a 5-kt explosive at a 2000-m depth (see Table 5).

2. Age of waste $=0.5 \mathrm{yr}$ (postirradiation time).

3. Duration of waste adcition $=25 \mathrm{yr}$.

4. Chimney temperatures kept below $200^{\circ} \mathrm{C}$ during waste addition.
5. Waste and water addition terminated at $25 \mathrm{yr}$.

The properties of the system were calculated at increments of $0.01 \mathrm{yr}$, using 1-m spatial zoning beyond the chimney. Figure 6 shows the rate of heat production peaking at about $67 \mathrm{MW}$. Figure 7 shows the total heat production reaching about $1.7 \times 10^{16} \mathrm{cal}$ at $100 \mathrm{yr}$. Figure $B$ shows the required rate of cooling-water addition reaching a maximum of about $1.8 \mathrm{~m}^{3} /$ min at the 25-yr cutoff. Figure 9 shows the radius of the molten rock mass reaching a maximum of $96 \mathrm{~m}$ at $90 \mathrm{yr}$.

Table 6 gives some further calculational results. These indicate that neither

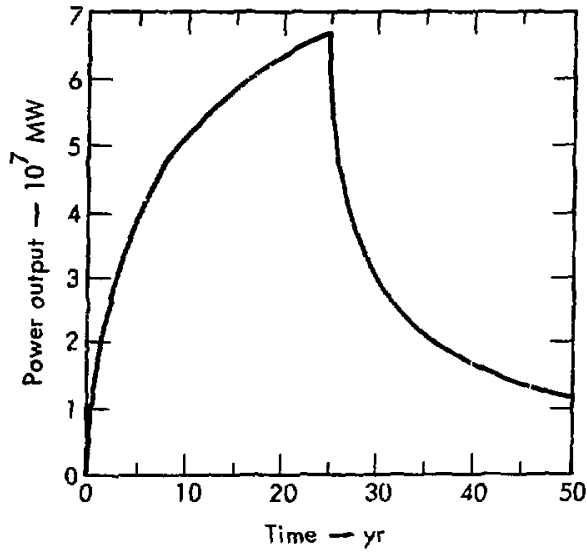

Fig. 6. Power output of waste versus time.

Table 5. Chimney data (depth $=2,000 \mathrm{~m}$, rock density $=2.7 \mathrm{~g} / \mathrm{cm}^{3}$, water content $=2: v t \%$.

\begin{tabular}{rcccc}
$\begin{array}{c}\text { Yield } \\
\text { (kt) }\end{array}$ & $\begin{array}{c}\text { Radius of } \\
\text { cavity } \\
(\mathrm{m})\end{array}$ & $\begin{array}{c}\text { Volume of } \\
\text { cavity } \\
\left(10^{3} \mathrm{~m}^{3}\right)\end{array}$ & $\begin{array}{c}\text { Bulking } \\
\text { porosity }\end{array}$ & $\begin{array}{c}\text { Mass of } \\
\text { chimney rubble } \\
\left(10^{10} \mathrm{~g}\right)\end{array}$ \\
\hline 5 & 10.8 & 5.31 & 0.52 & 1.32 \\
10 & 13.6 & 10.6 & 0.43 & 3.82 \\
30 & 19.7 & 31.9 & 0.32 & 28.6 \\
\hline
\end{tabular}




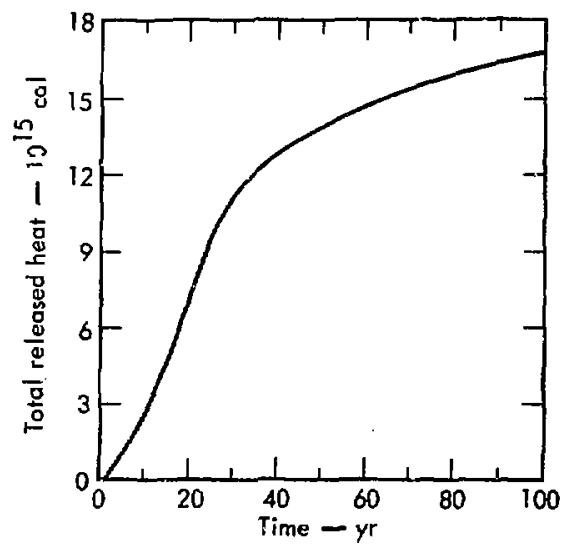

Fig. 7. Total released heat versus time.

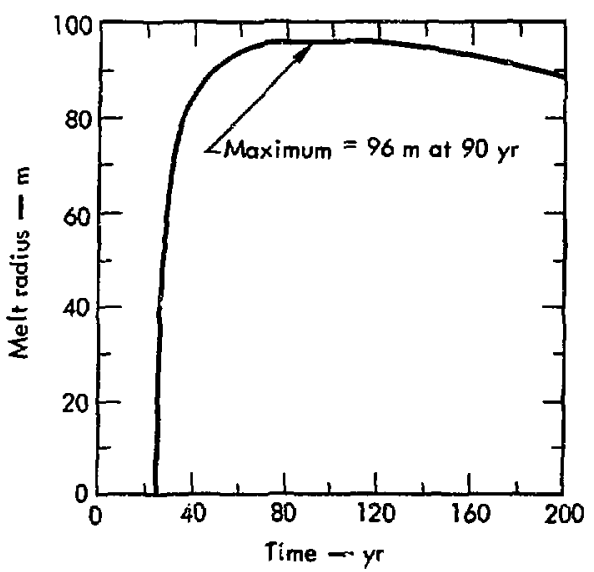

Fig. 9. Melt radius versus time.

the required cooling-water rate nor the rock-melting rate is significantly affected by the chimney size or by the assumption of $1 \cdot \mathrm{yr}$-old waste instead of $0.5-\mathrm{yr}$-old waste.

Other calculations performed with different spatial zonings $(0.5$ and $3.0 \mathrm{~m})$ and a controlled chimney temperature of

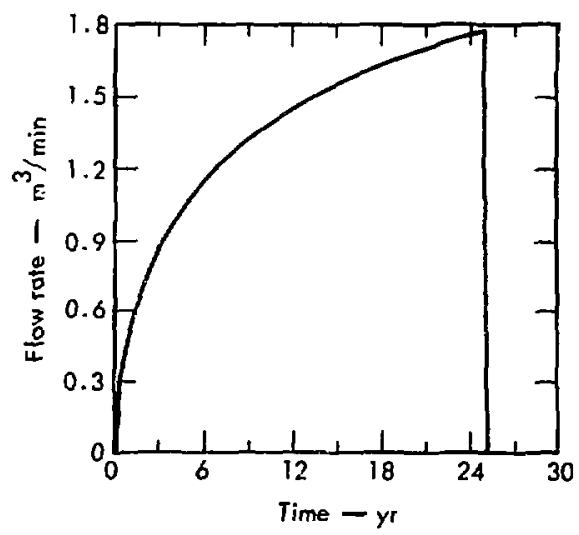

Fig. 8. Required cooling-water rate versus time.

Table 6. Effects of chimney size and age of waste.

\begin{tabular}{|c|c|c|c|c|}
\hline \multirow[b]{2}{*}{ Yield (kt) } & \multicolumn{3}{|c|}{$\begin{array}{c}\text { Age of waste } \\
-1 y x \\
\end{array}$} & \multirow{2}{*}{$\begin{array}{l}\begin{array}{c}\text { Age of } \\
\text { weste } \\
=0.5 \text { yr }\end{array} \\
5\end{array}$} \\
\hline & $\mathbf{5}$ & 10 & 30 & \\
\hline $\begin{array}{l}\text { Time at which chimney } \\
\text { can maintain dryness (yr) }\end{array}$ & 0.07 & 0.10 & 0.21 & 0.05 \\
\hline $\begin{array}{l}\text { Tirae at which chimney } \\
\text { has melted }\{y r\}\end{array}$ & 25.01 & 25.03 & 25.16 & 25.01 \\
\hline $\begin{array}{l}\text { Tulal volugne of cooling } \\
\text { water }\left(10^{6} \mathrm{~m}^{3}\right)\end{array}$ & 14.2 & 14.2 & 14.1 & 17.8 \\
\hline Molten-rock maximum & & & & \\
\hline Time (yr) & 90 & so & 90 & no \\
\hline Radius (n) & 96 & 96 & 96 & 96 \\
\hline
\end{tabular}

Cooling water added at the variable rete necessary to maintain the chimney temperature at $200^{\circ} \mathrm{C}$ during the $25-y$ period of waste addition.

$100^{\circ} \mathrm{C}$ indicate that these changes aiso have little effect on the overall phenomenology. Table 7 gives the effects due to variation in the assumed thermal properties of the rock. It is interesting to note from these data that changes in the thermal conductivity alter the times at which maximum melting occurs but do not significantly affect the total mass of melted rock, at least under the conditions $3 B-$ sumed for these calculations. 
Table 7. Effects of variation in the thermal properties of rock for the disposal of $0.5-y r-o l d$ waste in a 5-kt chimney.

\begin{tabular}{ccccc}
\hline $\begin{array}{c}\text { Heat of } \\
\text { fusion } \\
\text { (cal/g) }\end{array}$ & $\begin{array}{c}\text { Thermal } \\
\text { conductivity } \\
\text { (cal/cm-sec-deg) }\end{array}$ & $\begin{array}{c}\text { Specific heat } \\
\text { (cal/g-deg) }\end{array}$ & $\begin{array}{c}\text { Molten-rock maximum } \\
\text { Time (yr) }\end{array}$ \\
\hline 80 & $-\mathrm{b}$ & $-\mathrm{b}$ & 90 & Radius (m) \\
80 & $6 \times 1 c^{-3}$ & 0.23 & 68 & 96 \\
60 & $6 \times 10^{-3}$ & 0.23 & 66 & 93 \\
\hline
\end{tabular}

${ }^{a}$ Cooling water added at the variable rate necessary to maintain the chimney temperature at $200^{\circ} \mathrm{C}$ during the $25-\mathrm{yr}$ period of waste addition.

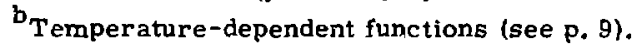

\section{Site Considerations}

Because transportation of liquid highlevel wastes is unacceptable, chimneys would have to be located at the sites of fuel-reprocessing plants. These sites must meet the requirements for both the reprocessing plant and the chimney, together with the required drill holes connecting the surface to the chimney. The site requirements discussed in this section are in addition to the usual plant requirements.

\section{SEISMIC ISOLATION}

Ground motion resulting from the shock wave of the explosion may cause damage to structures located close to the site. The explosive yield required to make a chimney of the size planned for this application is small enough (about $5 \mathrm{kt}$ ) that damage would be limited to a small area. As a guide, it is suggested that a site be selected that is $5 \mathrm{mi}$ or more from small towns and at least 10 to $15 \mathrm{mi}$ from major population centers so as to minimize the number of minor damage claims (cracked plaster, etc.) that might result. Generally, the degree of isolation required for plant-siting purposes would most likely be sufficient from the seismic standpoint also. ${ }^{17}$

A chimney or chimneys could be produced most simply prior to the construction of a plant, but if desired a plant could be designed and built to withstand the shock of a nearby 5-kt explnsive. If the plant were so construrted, cnimneys could be created as needed after construction and connected to the plant by a short pipeline.

\section{GEOLOGY AND HYDROLOGY}

Two phases of the operation must be considered in selecting a site with suitable geological and hydrological conditions. These are the waste-asdition phase and the rock-melting phase.

In the first phase, the chimney is connected to the surface through arill holes, waste and water are inti-oduced into the chimney, and steam is transported to the surface. In the second phase, after the volatiles are driven out of the chimney, 
the rock meits and the melt volume increases to some maximum size and then decreases as the melt freezes. In the example used here, the first phase lasts for $25 \mathrm{yr}$ and the second phase lasts for a few hundred years.

The chimney itself should be placed in rock having a low permeability. A rock layer $100 \mathrm{~m}$ or more thick is required to contain the chirnney and the associated fractures produced by the explosion. This ensures that a negligible amount of water enters the chimney prior to and during the early portion of the first phase and that no radioactivity migrates away from the chimney.

The requirement for the second phase is a low-water-content silicate rock of sufficient dimensions to contain the molten rock at its maximum dimension. For the example used in this paper, the maximum radius is $96 \mathrm{~m}$, which would require a material more than $200 \mathrm{~m}$ in thickness, and preferably 300 or $400 \mathrm{~m}$. This material should contain a negligible amount of carbonate rock in order to avoid the generation of $\mathrm{CO}_{2}$ during the melting phase. Once the rock starts to melt, the radioactive materials are dissolved in the melt and are soon surrounded by molten rock. The peripheral melt zone will coritain little or no radioactivity because of the high viscosity of silicate rocks near their meling point. Water in the surrounding sck would be converted to steam ahead of the advancing melt and would be driven away except for a small amount dissolved in the melt.

In order to provide further assurance that the waste is permanently isolated from the biosphere or from any water that might find its way to the surface, the chimney would be constructed at a depth greater than $2000 \mathrm{ft}$ and as deep as 1 or $2 \mathrm{mi}$, and below a considerable thickness of impermeable rock.

During the first phase when the drill holes are transporting water and steam between the chimney and the surface, care must be taken to avoid the introduction of radioactivity into rock zones containing mobile water. The system (chimney and holes) would be operated at a pressure less than that in any waterbearing zones except perhaps those within a few hundred feet of the surface. Any leak in the well casings below this depth or in the chimney would therefore be into the system rather than out of it. To avoid contamination in this shallow zone, a site should be selected with no important aquifers within several hundred feet of the surface, and preferal:y none at all. Multiple casing might be provided in this shallow zone, with instruments located between the inner and outer casinge to detect any leak so that corrective action could be taken. All holes would be cased, and tubing would be used within the casing to transport the waste.

The required geologic and hydrologic conditions for a site are commonly available and could be confirmed with minimum exploration costs. The site could probably be selected principally on the basis of the near-surface hydrology and the high expectation of finding a suitable chimney location at some reasonable depth based on general geologic knowledge of the region.

Once the chimney was constructed, its integrity and general suitability could be checked by pressure testing. Prior to the 
commencement of operations, the chimney would be instrumented for subsequent monitoring of ternperature and pressure conditions.

\section{Operational Considerations}

Figure 10 gives a generalized plan for an integrated nuclear fuel-reprocessing and waste-disposal facility. Initially, a short period (about $1 \mathrm{mo}$ ) of addition of high-level waste to the chimney would occur. Once the chimney becomes selfboiling, it will accept intermediate- and low-level waste as well as high-level waste. This waste plus the water from the condenser will be used to supply cooling water to the chimney. It may also be used to dilute the high-level waste before it enters the chimney or to flush the plumbing system after intermittant highlevel waste addition.

The high-level waste from the processing plant is contained in e. nitric-acid solution. If the solution i.3 not neutralized, the steam coming from the chimney will contain nitric acid. This nitric acid could be condensed and distilled in a fractionaldistillation column to provid-t both water and nitric acid for the processing plant, utilizing the steam energy for heating. Alternatively, the waste solution might be neutralized before introduction into the

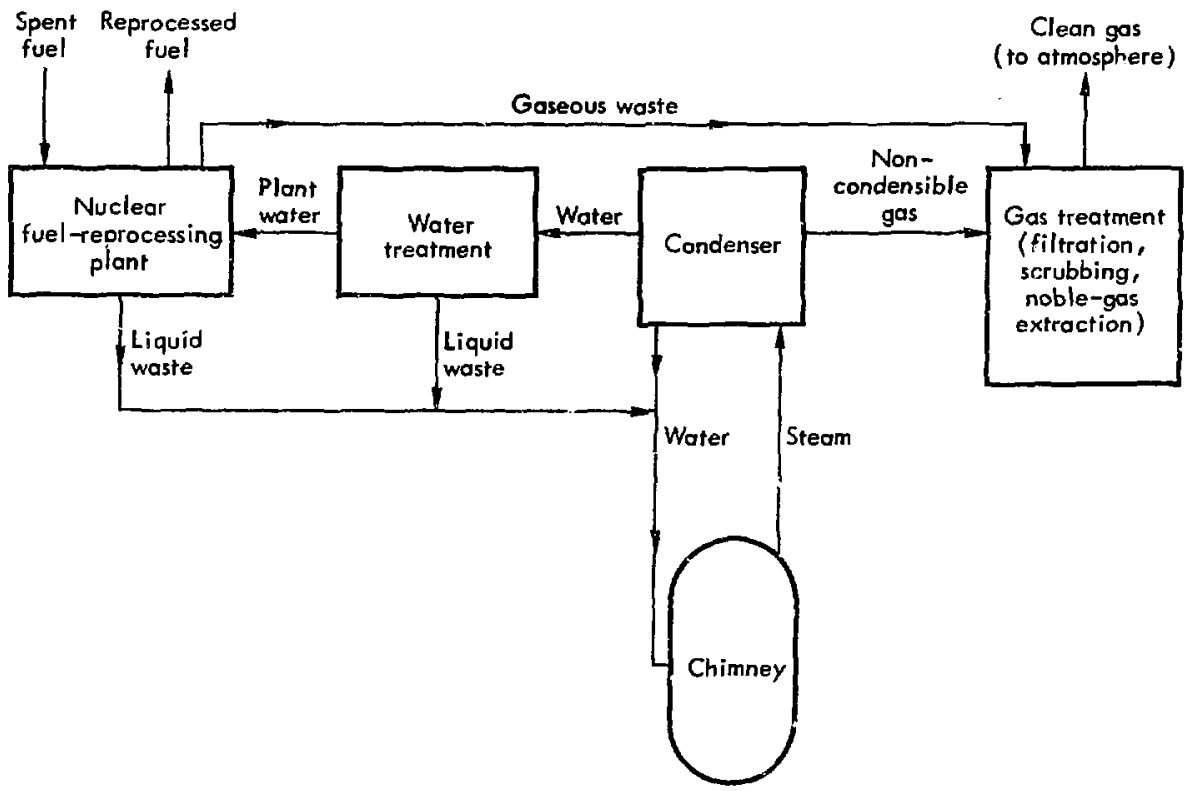

Fig. 10. Generalized flow diagram for an integrated nuclear fuel-reprocessing and waste-disposal facility. 
chimney. This would increase the volume of the solidified waste after evaporation.

The chimney capacity would be determined by the dry bulk volume of the waste and the storage volume of the chimney. Assuming a 5-kt chimney, as in Table $\delta$. at an allowable storage of $75 \%$ of maximum capacity, about $4000 \mathrm{~m}^{3}$ would be available. With a $3.3-\mathrm{ft}^{3}\left(0.093-\mathrm{m}^{3}\right) \mathrm{dry}$ bulk volume of waste per ton of fuel (Table 2), over 42,000 tons of fuel could be processed before capacity is reached. This would allow for $28 \mathrm{~g}:$ of operation at a rate of 1500 tons/yr. With preneutralization, the dry bulk volume would be increased hy an amount dependent on the method used. Some processes for the elimination of $\mathrm{HNO}_{3}$ might include the addition of alkali or organic reductants such as sugar of formaldehyde. ${ }^{5}$ Any increase in bulk volume could be accommodated by increasing the size of the chimney or by periodically allowing the chimney temperature to rise enough to ciecompose the nitrates, thereby decreasing the volume of solid in the chimney. The decomposition produsts, principally nitrogen oxides, would have to be processed at the surface for use or disposal.

The principal function of the condenser would be to circulate enough water into the chimney, and steam out, to keep the chimney well below the melting point of the rock during the operation of the facility. The amount of water required increases as the rate of heat generation in the chimney increases (Fig. 9). At its peak, the circulation required is about $1.8 \mathrm{~m}^{3} / \mathrm{min}$ of water $(237,090 \mathrm{lb} / \mathrm{hr}$ of steam). The hole size required to transport this amount of steam can be estimated from Fig. 11. ${ }^{18}$ For a depth of

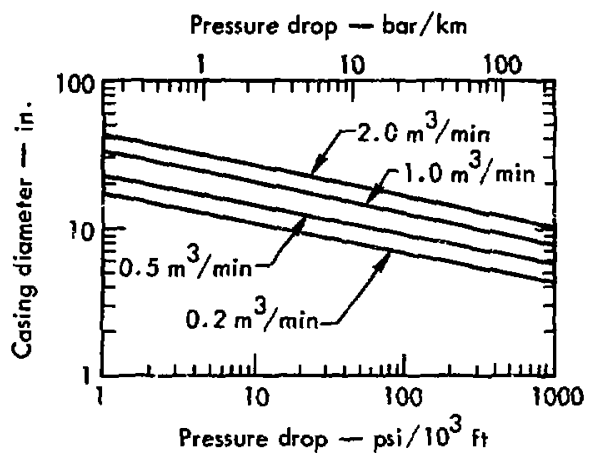

Fig. 11. Pressure drop for the flow of $200^{\circ} \mathrm{C}$ steam through a clean steel casing.

$2000 \mathrm{~m}$ and a temperature of $200^{\circ} \mathrm{C}$, a casing diameter of $22 \mathrm{in}$. is required for a pressure drop of less than 100 psi. Such a low pressure is desirable to reduce the transport of material in the steam and to maintain the chimney and the connecting casing at a low pressure relative to the surro'nding water-bearing zones.

The bulk of the water from the condenser can be reintroduced into the chimney as a coolant as required, without further treatment. Sufficient water (and perhaps $\mathrm{HNO}_{3}$ ) would be taken from the condenser and purified for reuse in the plant. Waste solutions from the watertreatment plant would be directed back into the chimney.

Considerable volumes of steam would be produced from the chimney, condensed, and recirculated. It is possible that this steam could be used to generate power. Energy is produced in the chimney at a rate of $40 \mathrm{MW}$ or more during the period from 5 to $25 \mathrm{yr}$ (Fig. 6). At $10 \%$ efficiency, 4 to $6 \mathrm{MW}$ of electrical power could be produced. This would require 
that the system be pressurized in order to obtain the high-pressure steam necessary to drive electrical generators. This pressure increase would present several possible problems.

As the pressure increases, the amount of material transported by the steam increases. These materials include silica and radioactivity which would have to be kept out of the turbine by using a heat exchanger, resulting in some loss of efficiency. Another problem is that an increase in the pressure could increase the possibility of a leak from the system into water-bearing zones. It is therefore not proposed to generate power initially. If these problems are examined and solved, it may be practical to generate power at some time in the future.

However, the large amount of heat available from the steam-condensation process can be utilized in the steamtreatment plant as well as in the fuelreprocessing plant without increasing the pressure, as would be required for direct sterm generation of power. This heat could be used for plant heating, distillation processes, or elsewhere as required.

\section{Economic Considerations}

As economic anaiysis of the present AEC methods for the management of highlevel liquid wastes is given in Ref. 5. This analysis gives the estimated costs for the various operaticnal components, the major ones being:

1. Pot calcination in cylinders.

2. Shipment to a salt mine.

3. Disposal in salt.

4. Interim liquid storage.

5. Interim solid storage.

The cost for the processing steps (items 1,2 , and 3 ) is shown to decrease rapidly with the age of the waste handled. Interim storage can be used to reduce the overall costs at only a moderate additional cost for storage facilities (Fig. 12). Using some combination of interim liquid and/or solid storage, an "optimum" disposal schedule can be obtained that is a compromise between cost and the desirability of disposing of the waste as soon as possible.

Using an economic model based on a discounted cash-flow method, ${ }^{5}$ the cost

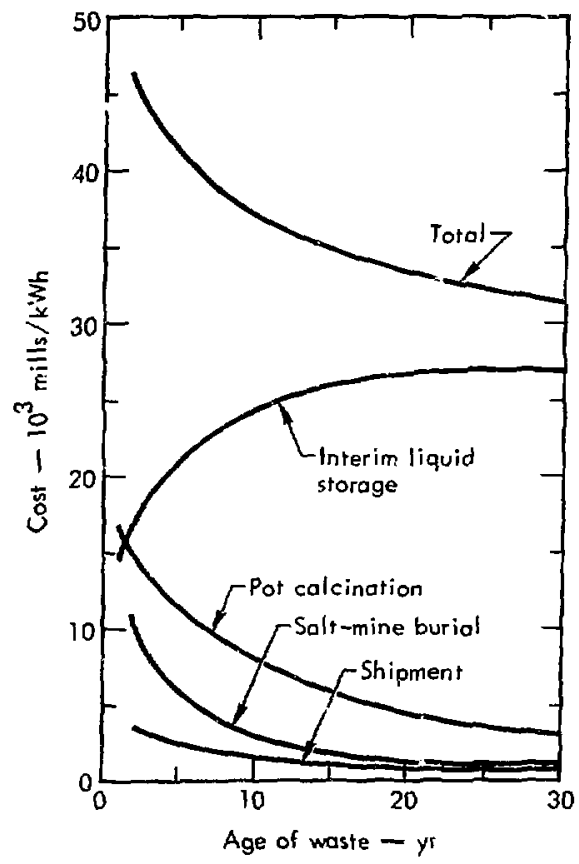

Fig. 12. Waste-management cost for solidification and salt-mine burial (calcined waste stored in 6 -in. -diam cylinders; no interim storage of solidified waste). 
estimates in Ref. 5 for high-level waste management by solidification and disposal in salt mines range from 0.03 to $0.05 \mathrm{mill}$ ! $\mathrm{kWhr}(\$ 7,650$ to $\$ 12,750$ per ton of fuel assuming a burnup of $33,000 \mathrm{MWd} /$ ton and $32 \%$ efficiency). The actual cost would be dependent to a large extent on the timing of the various processing steps.

The cost of disposing of intermediateand low-level liquid wastes (ILW and LLW) by means other than hydraulic fracfuring has been estimated ${ }^{19}$ at $\$ 1.65 / \mathrm{m}^{3}$ for wastes requiring a decontamination factor (DF) of less than 1000 and $\$ 120 / \mathrm{m}^{3}$ for a DF of $10^{4}$ to $10^{5}$. Assuming that ILW + LLW consists of $75 \%$ of the former and $25 \%$ of the latter, the average cost would be $\$ 31.24 / \mathrm{m}^{3}$. Assuming that $10,000 \mathrm{gal} /$ ton $\left(37.9 \mathrm{~m}^{3} /\right.$ ton $)$ are produced, an additional cost of avout $0.005 \mathrm{mill} /$ $k W h r_{e}(\$ 1,183 /$ ton) would be incurred.

The disposal cost of ILW and LLW by hydraulic fracturing techniques has been estimated $^{20}$ at $\$ 0.25 / \mathrm{gal}$. This would amount to about $0.01 \mathrm{mill} / \mathrm{kWhr}$ or $\$ 2,500 /$ ton.

To estimate the economics of liquidwaste disposal using the Plowshare concept, an analysis of costs for a typical reprocessing plant is made. For this analysis, a 5-ton/day plant is considered (1500 tons $/ \mathrm{yr}$ ). All the characteristics given in Table 2 are assumed. The plant life is assumed to be $25 \mathrm{yr}$. Over this period, 37,500 tons of fuel will have been processed, or the equivalent of about $10^{13} \mathrm{kWhr}$. Only waste-management costs are considered. Any economic advantage derived from integrating waste management with the fuel-reprocessing operation or any possible economic ken- efits due to energy recovery from the waste are neglected.

Table 8. Estimated capital costs of waste-management equipment and facilities for a 5-ton/day fuel-reprocessing plant using the Plowshare concept.

\begin{tabular}{|c|c|}
\hline Item & $\begin{array}{c}\text { Cost } \\
\left\{10^{6} \$\right\}\end{array}$ \\
\hline $\begin{array}{l}\text { Site selection (exploration } \\
\text { plus geologic studies) }\end{array}$ & 0.5 \\
\hline \multicolumn{2}{|l|}{ Drilling costs } \\
\hline Exploratory holes and testing & 1.5 \\
\hline Emplacement hole & 1.0 \\
\hline $\begin{array}{l}\text { Postshot reentry holes (vent } \\
\text { and injection holes plus } \\
\text { casing) }\end{array}$ & 2.0 \\
\hline $\begin{array}{l}\text { Explosive costs (fabrication, } \\
\text { transport, emplacement, } \\
\text { stemming, and firing) }\end{array}$ & 1.0 \\
\hline $\begin{array}{l}\text { Surface facilities (buildings, } \\
\text { tanks, pumps, and piping) }\end{array}$ & 2.0 \\
\hline $\begin{array}{l}\text { Environmental studies, safety, } \\
\text { and security }\end{array}$ & 1.0 \\
\hline Total & 10.0 \\
\hline
\end{tabular}

A breakdown of the estimated capital expenditures for equipment and facilities is given in Table 8 , which gives an estimated total of $\$ 10$ million. The estimated operational costs are based on a work force of 10 at an average salary plus overhead of $\$ 30,000 / \mathrm{man}-\mathrm{yr}$ plus $\$ 200,000 / y r$ for operational contingencies, giving a total of $\$ 500,000 / y r$. Based on a discounted cash-flow model and on economic assumptions that are consistent with those given in Ref, 5 , the average cost woulc be $\$ 1995 /$ ton or 0.008 mill/ $k W h r$. Table 9 gives a summary of the estimated cost for both treatment methods. 
Table 9. Comparative waste-management costs.

\begin{tabular}{|c|c|c|}
\hline & $\begin{array}{l}\text { AEC methods } \\
\left.(\text { mills/kWhr })_{e}\right)\end{array}$ & $\begin{array}{c}\text { Plowshare concept } \\
\text { (mills/kWhre })\end{array}$ \\
\hline High-] tevel liquid waste & 0.03 to 0.05 & \\
\hline $\begin{array}{l}\text { Low - and intermediate- } \\
\text { level liquid waste }\end{array}$ & 0.005 to 0.01 & $\sim 0.008$ \\
\hline Total & 0.035 to 0.06 & 0.008 \\
\hline
\end{tabular}

Waste-management costs using the Plowshare concept are much lower than those based on the most optimistic estimates for the solidification and salt-mineburial methods. It should also be noted that an increase in the plant capacity would have little effect on the total costs in the Plowshare concept, thereby significantly reducing unit costs. The esti- maied cost saving using the Plowshare concept as opposed to the present methods would range from 0.027 to $0.052 \mathrm{mill}$ / $\mathrm{kWhr}$. By the year 2000, when an estimated $4.4 \times 10^{12} \mathrm{kWhr} / \mathrm{yr}$ will be generated by nuclear reactors, use of the Plowshare concept could result in an annual savings ranging from $\$ 118$ million to $\$ 228$ million.

\section{Environmental Considerations}

The major concern with respect to nuclear waste disposal is the avordance of environmental pollution. Serious consequences could result from the release of only a small fraction of the radioactivity.

Because of its highly hazardous nature, high-level nuclear waste should be removed from the biosphere at the earliest possible time. In disposal methods involving solidification before disposal, early disposal of the waste is not possible without a significant economic sacrifice because of the high rate of heat generation in fresh wastes.

$\mathrm{Ec} \cdot \mathrm{h}$ operation in the wastesolidification process entails a certa:n potential for accidents. Transport of the solidified wastes also carries certain risks. Despite the extensive precautions planned for avoiding such hazards, the possibility of error or accident iucreases with the amount of handling and movement.

In the Plowshare concept, storage and processing are minimized and the need for transport of the wastes is eljminated. In addition, this concept offers several other environmental advantages:

1. Provision for the prompt elimination of the radioactive waste from the biospiere.

2. Permanent binding of the radicactive waste in a rock matrix deep underground, giving assurance of its permanent elimination from man's environment.

3. Provision of a safe method of permanently disposing of intermediate-. and low-level wastes. This would 
be true even for very-low-level wastes that normally are diluted and dispersed to the environment in concentrations presently considered safe.

Additional advantages include provision of a secure method of disposal safe from the effects of such disasters as floods, sabotage, or gerrilia warfare, and the possibility that a nonpolluting source of stcam for electrical power generation could be developed by utilizing the heat produced by the radioactive decay oi the wastes.

\section{Summary and Conclusions}

A method for nuclear waste management, called the Plowshare concept, is presented which has the following basic features:

1. Nuclear fuel reprocessing and waste management would be integrated at one common facility, eliminating the need for trinsportation of wastes.

2. Low-level and intermediate-level as well as high-level wastes would be injected into a deep underground chimney in a silicate rock and allowed to self-boil. The resulting steam would be processed and recirculated in a closed system.
3. Following a suitable period of waste addition, the chimney would be allowed to boil dry, thereby solidifying the $n$ astes. Subsequently, the heat generated by the radioactive wasta would melt the surrounding rock.

4. Finally, this melt would freeze, permanently trapping the radioactive raste in an insoluble rock matrix deep underground.

Since the Plowshare concept appear's to have significant environmental and economic advantages over previously proposed metlods, it should be seriously considered for future applications. 


\section{References}

1. D. Farney, "Atom-Age Trash: Fimding Places to Put Nuclear Waste Proves a Frightful Problem," Wall Street J., January 25, 1971.

2. "Siting of Commercial Fuel Reprocessing Plants and Related Waste Management Facilities," statement of Proposed Policy 10 CFR, Part 50, Fed. Reg. 35:222, p. 17530, November 4, 1970.

3. "Cornments on FR Doc. 69-6481," AEC Docket 50-1. Available from AEC Public Document Room, 1717 H Street NW, Washington, D.C.

4. "Comments on AEC Proposed Policy for Siting Fuel Reprocessing Plants," Atomic Energy Clearing House 17:5, p. 44, February 1, 1971. Available from Congressional Information Bureau, 4th and 6th Streets, NW, Washington, D. C.

5. Siting Fuel Repracessing Plants and Waste Management Facilities, Oak Ridge National Laboratory, Oak Sidge, Rept. ORNL-4451 (1970).

6. M. D. Nordyke, Underground Engineering Applications, Lawrence Radiation Laboratory. Livermore, Rept. UCRL-7 1453 (1969).

7. USA Standard Proposed Definition of Radioactive Waste Categories, American Institute of Chemical Engineering, 345 East 47 th Street, N. Y. (1967).

8. J. N. Nassikas, remarks to Electricai World Conference for Utility Executives, January 1971 , as quoted in Atomic Energy Clearing House 17:3, p. 2, January 18, $197 \mathrm{i}$.

9. Basic Factors for the Treatment and Disposal of Radioactive Wastes, IAEA Safety Series No. 24, International A tomic Energy Agency, Vienna (1967).

10. W. Je Laguna, "Radioactive Waste Disposal by Hydraulic Fracturing," Nucl. Saf. 11:5, p. 391, September 1970.

11. W. G. Belter, "The Manegement of Radioactive Wastes from Reactor Fuel Reprocessing," paper presented at the Atomic Industrial Forum Workshop, April 1970.

12. J. F. Froctor and I. W. Marine, "Geologic, Hydrologic, and Safety Considerations in the Storage of Radioactive Wastes in a Vault Excavated in Crystalline Rock," Nucl. Sci. Eng. 22:350 (1965).

13. J. C. Jaeger, "The Temperature in the Neighborhood of a Cooling Intrusive Sheet," Am. J. Sci. 255, 306 (1957).

14. R. W. Goranson, "Heat Caparity; Heat of Fusion," in Handbook of Physical Constants (Geologicai Society of America, Boulder, Colo., 1942), F. Birch, J. F. Schairer, and H. C. Spicer, Eds., p. 235.

15. S. P. Clark, "Thermal Conductivity," in Handbook of Physical Constants (Geologicai Society of America, Bouider, Colo., 1966), S. P. Clark, Ed., p. 474.

16. T. R. Butkovich and A. E. Lewis, Aids for Estimating Effects of Underground Nuclear Exploaions, Lawrence Radiation Laboratory, Livermore, Rept. UCRL50939 (1970). 
17. G. C. Rizer, A Method to Predict Seismic Damages to Residential Type Structures as a Result of Underground Nuclear Detonations, Lawrence Radiation Laboratory, Livermore, Rept. UCRL-50959 (1970).

18. 3. H. Perry, Perry's Chemical Engineers Handbook (McGraw-Hill, New York, 1963), 4th ed.. pp. 5-23.

19. Economics i3 Managing Radioactive Wastes, Tech. Rept. Series No. 83, International Atomic Energy Agency, Vienna (1968).

20. W. C. McCain, "Hydraulic Fracturing as a Waste Disposal Method," Proceedings of the Symposium on Disposal of Radioactive Waste into the Ground (International Atomic Energy Agency, Vienna, 1967). 
